\title{
Dependency of Accounting Data Quality on Selected Financial Indicators
}

\author{
Miroslava VLČKOVÁ \\ University of South Bohemia in České Budějovice. České Budějovice, Czech Repulic \\ mvlckova02@ef.jcu.cz
}

\begin{abstract}
The basic element for assessing the quality of accounting data is the level perceived by the users of accounting information; that is, to what extent the information approaches its requirements. High-quality accounting data reduces the risk for prospective investors, supports management and decisionmaking, and at the same time increases the ability of businesses to raise finance at a reasonable price. The aim of this paper, based on a survey determining the quality of accounting data, is to set the quality of the reported accounting data in the individual regions of the Czech Republic and at the same time determining whether this quality of accounting data develops depending, for example, on the total revenues of the company, expenses, cash flow and profit. Those financial indicators provide data on the performance, cash flows, and this information is used to evaluate the company's performance, to make high quality management decisions and the future plans.
\end{abstract}

Keywords: Quality of Accounting Data, Regions of the Czech Republic, EBIT, Cash Flow.

\section{Introduction}

The aim of financial accounting is to use relevant information regarding the property, sources of finance, costs, revenues and profit or loss based on the principle of true and fair view of accounting [2]. This basic role is subordinate to structure of assets and liabilities in the balance sheet - in terms of their long-term and short-term, in terms of liquidity, leverage, etc., as well as content costs, revenues and profit concept in the profit and loss account.

The quality of accounting information also depends on the quality of the management and presentation of the accounting data, but also on the quality of the financial statements and their compliance with reality and the applicable laws. Some companies require only a mechanical application of the accounting rules, while others rely on the decision of the company managers and accountants. Error rate and creative accounting are generally viewed as negative phenomena, i.e. accountants have to admit that they error, which could be understood as poorly executed work or even fraud where creative accounting is concerned [13].

Some authors $[5,11]$ and others say that one of the greatest influences in achieving above-average quality is the involvement of top management, which plays an 
important role in this field. And [6] says that for the successful implementation of quality is necessary support for motivation, teamwork and the use of quality management tools and techniques. The aim of accounting information is to provide information necessary for the management and prepare reports based on which they decide [1]. If the quality is set in accordance with the comprehensive determination of quality, the enterprise will be able to succeed in today's society [9]. The benefit of the quality of information, offered through financial reports, is proven in the conditions in which the users use the information in order to understand the economic reality of the enterprise, and in order to make decisions. Thus the accounting information benefit has to be defined only through its quality $[4,14]$.

Other authors [12] have the opinion that if the quality control is carried out effectively the company can have considerable results especially from the financial point of view. Enterprises that have successfully established management systems achieve higher performance and better financial results. A number of prosperous businesses can see that a good quality information system and, above all, a sophisticated system of managerial accounting contribute to their successful management. These businesses know that they will only be able to compete in a competitive environment if they are able to effectively manage their costs and revenues, cash flow, profits, accounting and other financial value information needed for quality and efficient management. In many companies we can see that for their successful management highly contributes quality information system. The companies use the quality of accounting data throughout its life cycle [10]. From the perspective of the user requirements, the quality is defined as suitability to use in the economic calculations [8]. It is generally known that the quality of accounting information in the companies is usually not in very good condition and at the same time there is a reduction in the ability of managers.

\section{$2 \quad$ Methodology}

This article aims at assessing the quality of the reported accounting data according to predefined criteria in the individual regions of the Czech Republic and at the same time determining whether this quality of accounting data develops depending, for example, on the total revenues of the company, expense, cash flow and profit.

The method used for evaluation of quality of accounting data is DQAD (determination of quality of accounting data). This method is composed based to the criteria which have the biggest impact to the quality of accounting data and to the management as well [15]. Those criteria were divided into three groups - first group is Errors and fraud, second group is Accounting Methodology and third group is Influence to information system in a company.

The first group is composed of four criteria:

- accounting fraud by management, unethical behavior,

- accounting fraud by employees, unethical behavior,

- creative accounting and

- accounting errors arising out ignorance, human accounts error. 
The second group is composed of five criteria:

- methods of depreciation,

- methods of valuation,

- methods of accounting organization, processing,

- internal directive and

- internal control.

The third group is composed of three criteria:

- lack of information, poor internal communication,

- legislation - too wide or narrow, confusion, frequent changes and

- requirements for managers to information system.

Based on these criteria was, by the using the methods AHP (Analytic Hierarchy Process) and Multiple Linear Regression, composed this model to determining quality of accounting [15]:

$D Q A D=1,746+1,326 * x 1+0,002 * x 2-0,236 * x 3-0,378 * x 4+0,075 * x 5$

where:

$\mathrm{x} 1$ is the value of the indicator (Adjusting Entries + Reserves) / Total Asset,

$\mathrm{x} 2$ is the value of the indicator Cash Flow / EBIT,

$\mathrm{x} 3$ is the value of the indicator Revenue / Total Asset,

$\mathrm{x} 4$ is the value of the indicator Cash Flow / Liability,

$\mathrm{x} 5$ is the value of the indicator Interest / Cash Flow.

The higher the value of accounting data quality is the worst quality of accounting data in the company is. It is on base that the criteria have negative position in the company. The range for accounting data quality was compiled:

To 0,8

From 0,81 to 1,6

From 1,61 to 2,4

From 2,41 to 3,2

very good quality,

good quality,

average quality,

bad quality,

Up to 3,21

very bad quality.

Regression analysis is a set of statistical processes for estimating the relationships among variables. More specifically, regression analysis helps one understand how the typical value of the dependent variable changes when any one of the independent variables is varied.

$$
y=\left(b_{0}+b_{1} x_{1}\right)
$$

which describes a line with slope $b_{1}$ and $y$-intercept $b_{0}$ [7].

The zero hypothesis $\mathrm{H} 0$ was set that both groups are equal over against HA, where the two samples are different. 


\section{$3 \quad$ Results}

The model DQAD (determination of quality of accounting data) was applied for 23 587 companies. There were companies from all regions of the Czech Republic, with number of employees from 10. Data are obtained from the Albertina Gold Edition database for the period 2015.

Firstly, the quality of accounting data in the companies were detected in each region of the Czech Republic. The quality of accounting data you can see in the picture 1 and in the table 1 .

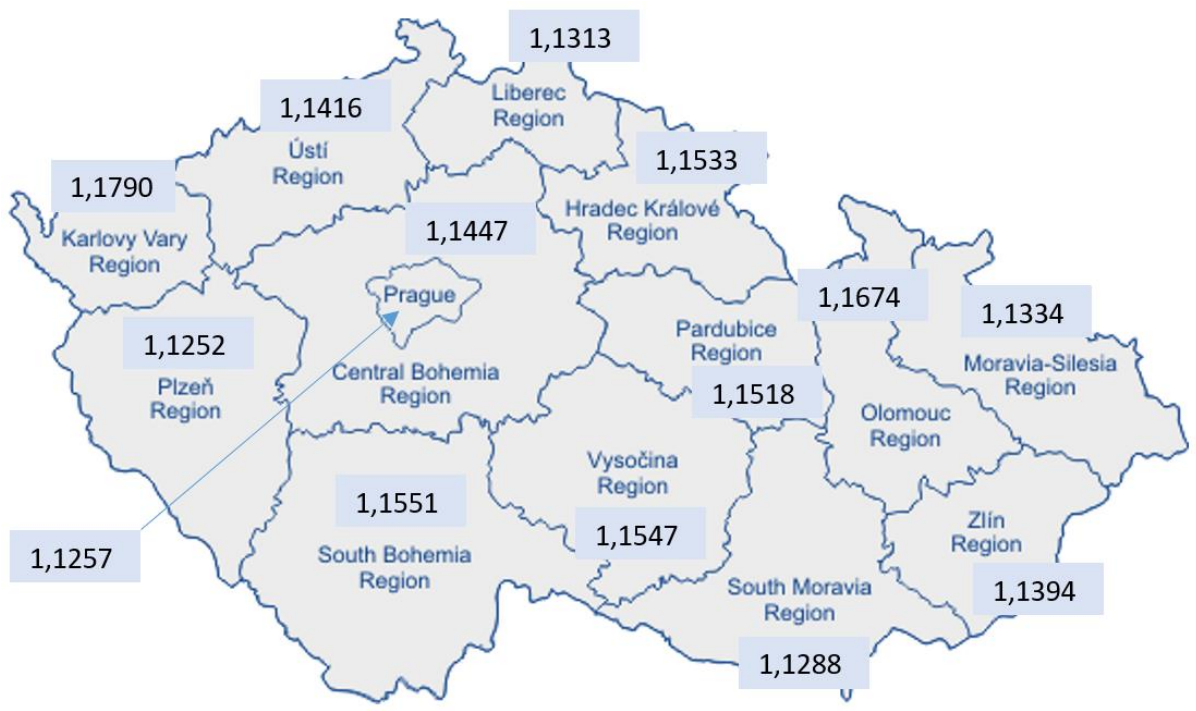

Fig. 1. Quality of accounting data in the regions of the Czech Republic.

It is seen that the best quality of accounting data is in Prague, then in Plzen Region and in South-Moravia Region. On the other side, the worst quality of accounting data is in Hradec Králové Region, in Vysočina Region and in South Bohemia Region. The numbers of analyzed companies are in the next table.

Table 1. Quality of accounting data in the regions of the Czech Republic.

\begin{tabular}{|l|c|c|}
\hline Region & $\begin{array}{c}\text { Number of } \\
\text { companies }\end{array}$ & $\begin{array}{c}\text { Quality } \\
\text { average }\end{array}$ \\
\hline Prague & 5741 & 1,1257 \\
\hline Plzeň Region & 1148 & 1,1252 \\
\hline South-Moravia Region & 2963 & 1,1288 \\
\hline Liberec Region & 760 & 1,1313 \\
\hline
\end{tabular}




\begin{tabular}{|l|c|c|}
\hline Moravia-Silesia Region & 2041 & 1,1334 \\
\hline Zlín Region & 1335 & 1,1394 \\
\hline Ústi Region & 1232 & 1,1416 \\
\hline Central Bohemia Region & 2017 & 1,1447 \\
\hline Pardubice Region & 1082 & 1,1518 \\
\hline Hradec Kralové Region & 1248 & 1,1533 \\
\hline Vysočina Region & 1039 & 1,1547 \\
\hline South Bohemia Region & 1241 & 1,1551 \\
\hline Olomouc Region & 1251 & 1,1674 \\
\hline Karlovy Vary Region & 489 & 1,1790 \\
\hline Total & $\mathbf{2 3 5 8 7}$ & $\mathbf{1 , 1 4 5 1}$ \\
\hline
\end{tabular}

The next step was to investigate whether there is a dependency between the quality of the accounting data and selected financial indicators. These indicators included EBIT, Total Revenues, Cash Flow and Total Cost Ratio. Linear regression was used as a statistical test to determine dependence. The results of this regression are in the following table and graphs.

Table 2. Results of statistical analyses.

\begin{tabular}{|l|r|r|r|r|r|r|}
\hline Variable & $\begin{array}{c}\text { Distrib. } \\
\text { frequenc. } \\
\text { model }\end{array}$ & $\begin{array}{r}\text { Sum of } \\
\text { squares } \\
\text { residual }\end{array}$ & $\begin{array}{c}\text { DoF } \\
\text { residual }\end{array}$ & $\begin{array}{c}\text { Distrib. } \\
\text { frequenc. } \\
\text { residual }\end{array}$ & F & p-value \\
\hline EBIT & 1,84430 & 3811,28 & 23585 & 0,16159 & 11,4129 & 0,00073 \\
\hline Total Revenues & 2,85868 & 3810,26 & 23585 & 0,16155 & 17,6948 & 0,00002 \\
\hline Cash Flow & 0,06122 & 3813,06 & 23585 & 0,16167 & 0,37868 & 0,53831 \\
\hline $\begin{array}{l}\text { Total Cost } \\
\text { Ratio }\end{array}$ & 8,31393 & 3804,81 & 23585 & 0,16132 & 51,5358 & 0,00000 \\
\hline
\end{tabular}

From a statistical point of view, there was a comparison of indicators EBIT, Total Revenues and Total Cost Ratio with the quality of accounting data, when these financial indicators rejected a zero hypothesis $\mathrm{HO}$ in favor of HA, where in those cases the value of the p-value is less than 0.05. Analysis between the quality of the accounting data and Cash Flow does not prove significant differences at significance level of 0.05 . P-value in Cash Flow was found at 0.53831 . In this case a zero hypothesis $\mathrm{H} 0$ was not rejected in favor of $\mathrm{HA}$ and we can say that there is a 
dependency between the quality of the accounting data and financial indicator Cash Flow.

On the following graphs we can see the histograms of residues for the selected criteria. Analysis of the residue gives us information about the suitability of the used model. As a selected criteria were used one criterion that confirmed the zero hypothesis and one criterion that did not confirm the zero hypothesis. For illustration, the Cash Flow and Total Cost Ratio criteria were selected.

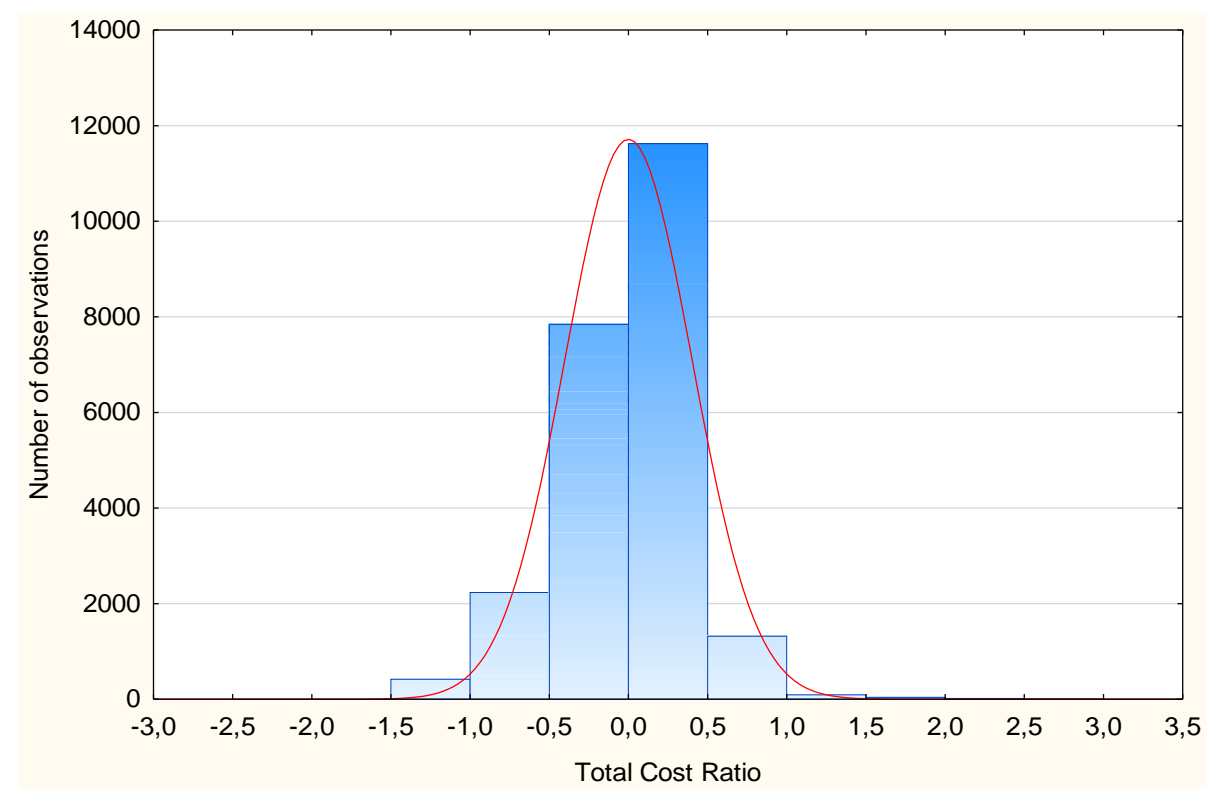

Fig. 2. A histogram of net residues - Total Cost Ratio

A histogram of residues is a graphical representation of the distribution of residues. It is an estimate of the probability distribution of a continuous variable. Both histograms of the residues are symmetric, its shape corresponds approximately to the Gaussian curve. 


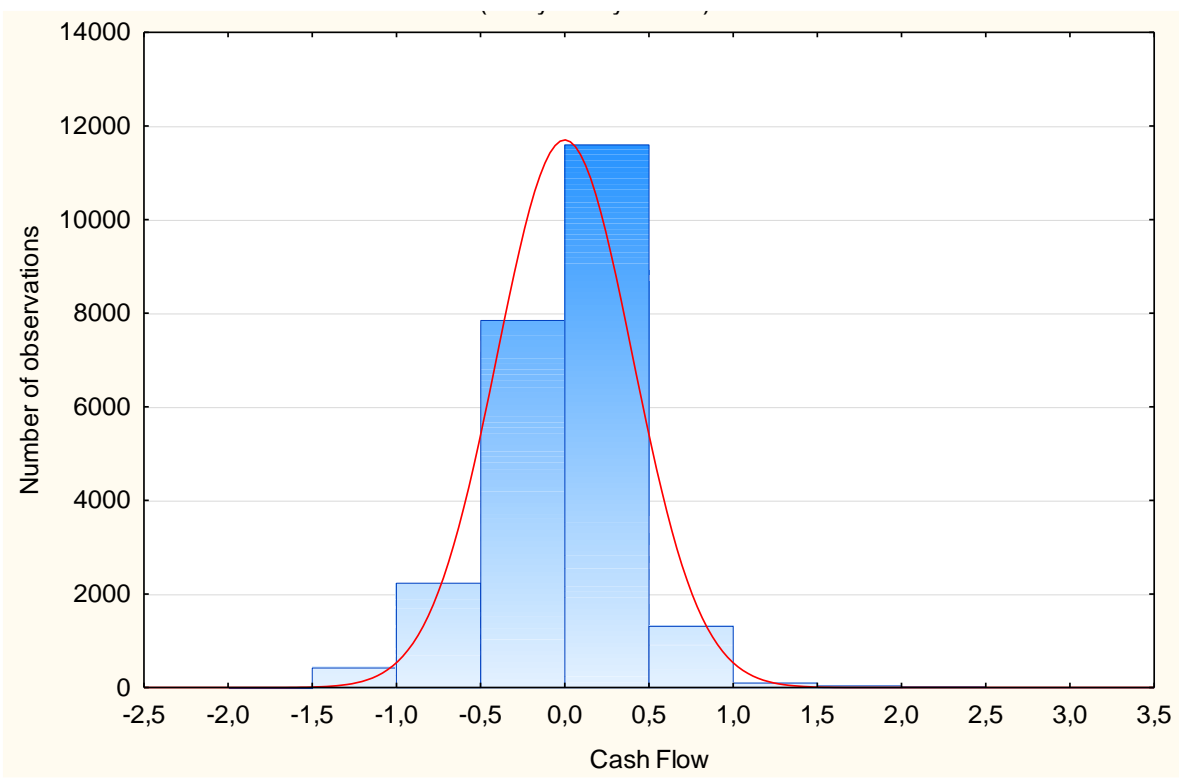

Fig. 3. A histogram of net residues - Cash Flow

Source: Own research

\section{Discussion}

Accounting system is designed as a process of collecting information and creating accounting reports.

Donnelly [3] argue that the more quality information the managers have the more the level of risk and uncertainty in their decisions are reduced. The output of financial accounting information is often poor because of several reasons. These are, in particular, the possibilities of influencing accounting data, even within the framework of legislative regulations.

During the analyzing the quality of accounting data in the individual regions of the Czech Republic, it was interesting to find out that the highest quality was found in Prague. Moreover, Prague is the concentration of most businesses of all cities in the Czech Republic, and there is the highest concentration of medium and large enterprises. An analysis of the quality of accounting data by company size would also be interesting. On the other hand, the worst quality of accounting data was demonstrated in the Karlovy Vary region, the Olomouc region and the South Bohemia region.

The basic objective of financial accounting is to provide relevant information regarding the property, sources of financing, costs, revenues and profit or loss based on the principle of true and fair view of accounting. This basic role is subordinate to structure of assets and liabilities in the balance sheet - in terms of their long-term and 
short-term, in terms of liquidity, leverage, etc., as well as content costs, revenues and profit concept in the profit and loss account. Although the difference in the average quality of the accounting data in each region was not very large, it should be noted that the differences between the individual enterprises were. Not all businesses are thus provided true and fair view.

The results of the statistical analysis were interesting. Although the Cash Flow value is found in the used DQAD model, this indicator did not appear to be statistically significant in relation to the quality of the accounting data.

\section{Conclusion}

The more quality information the managers have the more the level of risk and uncertainty in their decisions are reduced. Increased emphasis on compliance with the financial discipline and internal control of accounting data can significantly contribute to improving the quality of accounting information, especially with regard to making decisions. The article is primarily concerned with analysis of the accounting data quality and selected indicators of financial analysis. In the first step the values of data quality accounting were detected and evaluated depending on the regions of the Czech Republic. The model DQAD was used for 23587 companies and indicators of financial analysis was calculate. Analysis between the quality of the accounting data and EBIT, Total Revenues and Total Cost Ratio prove significant differences at significance level of 0.05 .

\section{References}

1. Baba, M. C.: Quality management of the accounting services. Bulletin of the Transilvania University of Brasov. Vol. 2 (51) (2009).

2. Česká republika. Zákon č. 563/1991 Sb., o účetnictví.

3. Donnelly, J. H., Gibson, J. L., Inancevich, J. M.: Management. Praha: Grada Publishing (2008).

4. Dumitru, G.: The Accounting Information Quality Concept. Economics, Management and Financial Markets, 7(4), 326-336, (2012).

5. Ehigie, B. O., Akpan, R. C.: Roles of perceived leadership styles and rewards in the practice of total quality management. Leadership and Organization Development Journal, 25(1-2), pp. 24-40, (2004).

6. Eriksson, H.: Organizational Value of Participating in Quality Award Processes. Doctoral Thesis. Lulea: University of Technology. (2003).

7. Hendl, J.: Přehled statistických metod. Analýza a metaanalýza dat. 4. vyd. Praha: Portál, s.r.o. (2012).

8. Juran, J. M.: Juran on Quality by Design. Reed. New York: The Free Press (1992).

9. Kanji, G. K., Wallace, W.: Business excellence through customer satisfaction. Total Quality Management, vol. 11 (7), pp. 979-998, (2000).

10. Laptes, R.: Accountancy of the present - standardized social practice through financial statements. Transilvania University of Brasov [online]. pp. 171-176 (2009) 
http://search.proquest.com/docview/209548550/abstract?accountid=9646 last accessed 2012/02/29.

11. Motwani, J.: Critical factors and performance measures of TQM. The TQM Magazine, 13(4), pp. 292-300, (2001).

12. Nenadál J., Noskievicová, D. Petríková, R. Plura, J. Tošenovský, J.: Moderní systémy ř́zení jakosti. 2nd reed. Praha: Management Press (2002).

13. Paseková, M., Svitaková, B., Kramá, E., \& Otrusinová, M.: Towards financial sustainability of companies: issues related to reporting errors, Journal of Security and Sustainability Issues 7(1): 141-153, (2017). http://dx.doi.org/10.9770/jssi.2016.7.1(12)

14. Večerskienè, G., Valančienè, L., \& Boguslauskas V.: Training Accounting Specialists at Kaunas University of Technology Economics and Management Faculty: Past, Present and Perspectives. Inzinerine Ekonomika-Engineering Economics, 4(59): 9-17, (2008). Available from: http://inzeko.ktu.lt/index.php/EE/article/view/11570

15. Vlčková, M.: The quality of accounting data in management-level of business. České Budějovice, 2014. 150 p. (2014). Faculty of Economics. University of South Bohemia in České Budějovice. 